\title{
Pseudomonas rhizosphaerae sp. nov., a novel species that actively solubilizes phosphate in vitro
}

Correspondence

Encarna Velázquez evp@gugu.usal.es

\author{
Alvaro Peix, ${ }^{1}$ Raúl Rivas, ${ }^{2}$ Pedro F. Mateos, ${ }^{2}$ Eustoquio Martínez-Molina, ${ }^{2}$ \\ Claudino Rodríguez-Barrueco ${ }^{1}$ and Encarna Velázquez ${ }^{2}$ \\ ${ }^{1}$ Instituto de Recursos Naturales y Agrobiología, CSIC, Salamanca, Spain \\ 2Departamento de Microbiología y Genética, Lab. 209, Edificio Departamental de Biología, \\ Campus M. Unamuno Universidad de Salamanca, 37007 Salamanca, Spain
}

\begin{abstract}
A bacterial strain (designated $\mathrm{IH} 5^{\top}$ ), isolated from rhizospheric soil of grasses growing spontaneously in Spanish soil, actively solubilized phosphates in vitro when bicalcium phosphate was used as a phosphorus source. This strain was Gram-negative, strictly aerobic, rod-shaped and motile. The strain produced catalase, but not oxidase. Cellulose, casein, starch, gelatin, aesculin and urea were not hydrolysed. Growth was observed with many carbohydrates as the carbon source. The main non-polar fatty acids detected were hexadecenoic acid $\left(\mathrm{C}_{16: 1}\right)$, hexadecanoic acid $\left(\mathrm{C}_{16: 0}\right)$ and octadecenoic acid $\left(\mathrm{C}_{18: 1}\right)$. The hydroxy fatty acids detected were 3-hydroxydecanoic acid $\left(\mathrm{C}_{10: 0} 3-\mathrm{OH}\right)$, 3-hydroxydodecanoic acid $\left(\mathrm{C}_{12: 0} 3-\mathrm{OH}\right)$ and 2-hydroxydodecanoic acid $\left(\mathrm{C}_{12: 0} 2-\mathrm{OH}\right)$. Phylogenetic analysis of $16 \mathrm{~S}$ rRNA indicated that this bacterium belongs to the genus Pseudomonas in the $\gamma$-subclass of the Proteobacteria and that the closest related species is Pseudomonas graminis. The DNA G+C content was $61 \mathrm{~mol} \%$. DNA-DNA hybridization showed $23 \%$ relatedness between strain $\mathrm{IH}^{\top}$ and $P$. graminis DSM $11363^{\top}$. Therefore, strain $1 \mathrm{H} 5^{\top}$ belongs to a novel species from the genus Pseudomonas, for which the name Pseudomonas rhizosphaerae sp. nov. is proposed (type strain, $\mathrm{IH}^{\top}=\mathrm{LMG}$ $21640^{\top}=$ CECT $5726^{\top}$ ).
\end{abstract}

Phosphorus is an essential plant nutrient that is added to soil as soluble inorganic phosphates, a large proportion of which becomes insoluble and therefore unavailable to plants (Singh \& Kapoor, 1994). Many species of bacteria are able to solubilize phosphates in vitro and most of them live in the plant rhizosphere. At present, bacilli, rhizobia and pseudomonads are the most studied phosphate-solubilizers (Rodríguez \& Fraga, 1999). Nevertheless, only a small number of species that presently belong to the genus Pseudomonas sensu stricto are known to be phosphatesolubilizers and they all belong to rRNA group I (Palleroni et al., 1973; Palleroni, 1992). Pseudomonas putida (Viveganandan \& Jauhri, 2000; Kumar \& Singh, 2001; Manna et al., 2001; Villegas \& Fortin, 2002), Pseudomonas aeruginosa (Musarrat et al., 2000), Pseudomonas corrugata (Pandey \& Palni, 1998), Pseudomonas stutzeri (Vázquez et al., 2000) and Pseudomonas fluorescens (Di Simine et al., 1998; Deubel et al., 2000) are the most studied species. Nevertheless, many rhizospheric, phosphate-solubilizing bacterial species remain unknown

Published online ahead of print on 27 June 2003 as DOI 10.1099/ ijs.0.02703-0.

The GenBank/EMBL/DDBJ accession number for the 16S rRNA gene sequence of strain $1 \mathrm{H} 5^{\top}$ is $A Y 152673$.

Electron micrographs of strain $1 \mathrm{H} 5^{\top}$ and a full phylogenetic tree are available as supplementary material in IJSEM Online. and more studies are needed to reveal the high biodiversity of these bacteria. Although the study of rhizospheric bacteria is difficult, due to the high number of bacteria present in soil, characterization and identification of these bacteria are necessary for wide ecological studies of the plant rhizosphere.

During a wide study of phosphate-solubilizing, rhizospheric bacteria in soils from northern Spain, we isolated a strain that produced a yellow pigment in media that contained glucose as the carbon source and formed a transparent 'halo' around its colonies in media that contained insoluble bicalcium phosphate as the phosphorus source.

A sample of rhizospheric soil of grasses was collected under aseptic conditions from land in northern Spain; $10 \mathrm{~g}$ was suspended in $90 \mathrm{ml}$ sterile water and stirred for $30 \mathrm{~min}$. From this suspension, $100 \mu$ l was spread on YED-P medium ( $7 \mathrm{~g}$ glucose $1^{-1}, 3 \mathrm{~g}$ yeast extract $\mathrm{l}^{-1}, 3 \mathrm{~g}$ bicalcium phosphate $1^{-1}$ and $17 \mathrm{~g}$ agar $\mathrm{l}^{-1}$ ) and incubated at $28^{\circ} \mathrm{C}$. A bacterial strain that actively solubilized phosphate was isolated. This strain, designated $\mathrm{IH} 5^{\mathrm{T}}$, was maintained as a glycerol suspension $[25 \%(\mathrm{v} / \mathrm{v})]$ at $-80{ }^{\circ} \mathrm{C}$.

Strain $\mathrm{IH}^{\mathrm{T}}$ was grown in nutrient agar medium for $48 \mathrm{~h}$ at $22{ }^{\circ} \mathrm{C}$ to check for motility by phase-contrast microscopy. Cells were also stained according to the classical 
Gram procedure described by Doetsch (1981). For electron microscopy, cells were grown on nutrient agar for 2 days then suspended gently in sterile water, stained with $0 \cdot 2 \%$ uranyl acetate and examined at $80 \mathrm{kV}$ with a Zeiss EM 209 transmission electron microscope. Strain $\mathrm{IH}^{\mathrm{T}}$ is a Gramnegative, rod-shaped organism $(1 \cdot 2-2 \cdot 4 \times 0 \cdot 8-0 \cdot 9 \mu \mathrm{m})$. Cells are motile with a polar flagellum (see Supplementary Fig. I, available in IJSEM Online) and grew as weakly translucent, yellow-coloured colonies on nutrient agar.

For $16 \mathrm{~S}$ rDNA sequencing, DNA extraction was carried out as described previously (Rivas et al., 2001). Amplification and sequencing of $16 \mathrm{~S}$ rDNA were performed as described previously (Rivas et al., 2003a). The sequence obtained was compared with those in GenBank by using the FASTA program (Pearson \& Lipman, 1988). Sequences were aligned by using CLUSTAL W software (Thompson et al., 1997). Distances were calculated according to the methods of Jukes \& Cantor (1969), Kimura (1980), Tajima \& Nei (1984) and Tamura \& Nei (1993). Phylogenetic trees were inferred by using the neighbour-joining (Saitou \& Nei, 1987), maximum-likelihood (Yang, 1997) and parsimony (Felsenstein, 1983) analysis methods. Bootstrap analysis was based on 1000 resamplings. The MEGA 2.1.0 package (Kumar et al., 2001) was used for all analyses. Trees were rooted by using Burkholderia graminis as the outgroup.

The complete 16S rDNA sequence for isolate $\mathrm{IH} 5^{\mathrm{T}}$ (GenBank accession no. AY152673) was obtained (1531 nt). Comparison with all 16S rDNA sequences of Pseudomonas species with validly published names held in GenBank indicated that the organism is related phylogenetically to members of this genus. A phylogenetic tree obtained with Kimura's two-parameter model and the neighbour-joining method that included representative species of the genus Pseudomonas sensu stricto according to Anzai et al. (2000) and the recently described species Pseudomonas grimontii (Baïda et al., 2002), Pseudomonas kilonensis (Sikorski et al., 2001), Pseudomonas lini (Delorme et al., 2002), Pseudomonas tremae, Pseudomonas cannabina (Gardan et al., 1999), Pseudomonas cremoricolorata and Pseudomonas parafulva (Uchino et al., 2001) showed that strain $\mathrm{IH}^{\mathrm{T}}$ forms a separate group with $P$. graminis DSM $11363^{\mathrm{T}}$ (see Supplementary Fig. II, available in IJSEM Online). Fig. 1 shows the phylogenetic placement of strain $\mathrm{IH}^{\mathrm{T}}$ within the genus Pseudomonas. The same results were obtained when phylogenetic distances were calculated by using the Jukes-Cantor one-parameter, Kimura two-parameter, Tamura-Nei three-parameter and Tajima-Nei fourparameter models. Trees obtained with the neighbourjoining, maximum-likelihood and parsimony methods (using, with each one, the four models already mentioned to calculate phylogenetic distances) also showed the same results (data not shown). Sequence similarity, based on pairwise sequence comparisons, was investigated by using complete $16 \mathrm{~S}$ rDNA sequences. The data obtained showed that the 16S rDNA sequence of strain $\mathrm{IH}^{\mathrm{T}}$ shows $97-98 \%$ similarity to many species of the genus Pseudomonas sensu stricto, except in the case of $P$. graminis (to which it shows $99 \%$ similarity). Therefore, $P$. graminis and strain $\mathrm{IH}^{\mathrm{T}}$ form a group within the genus Pseudomonas that is clearly distinguishable from the other species, based on 16S rRNA gene sequences. These results are in agreement with those

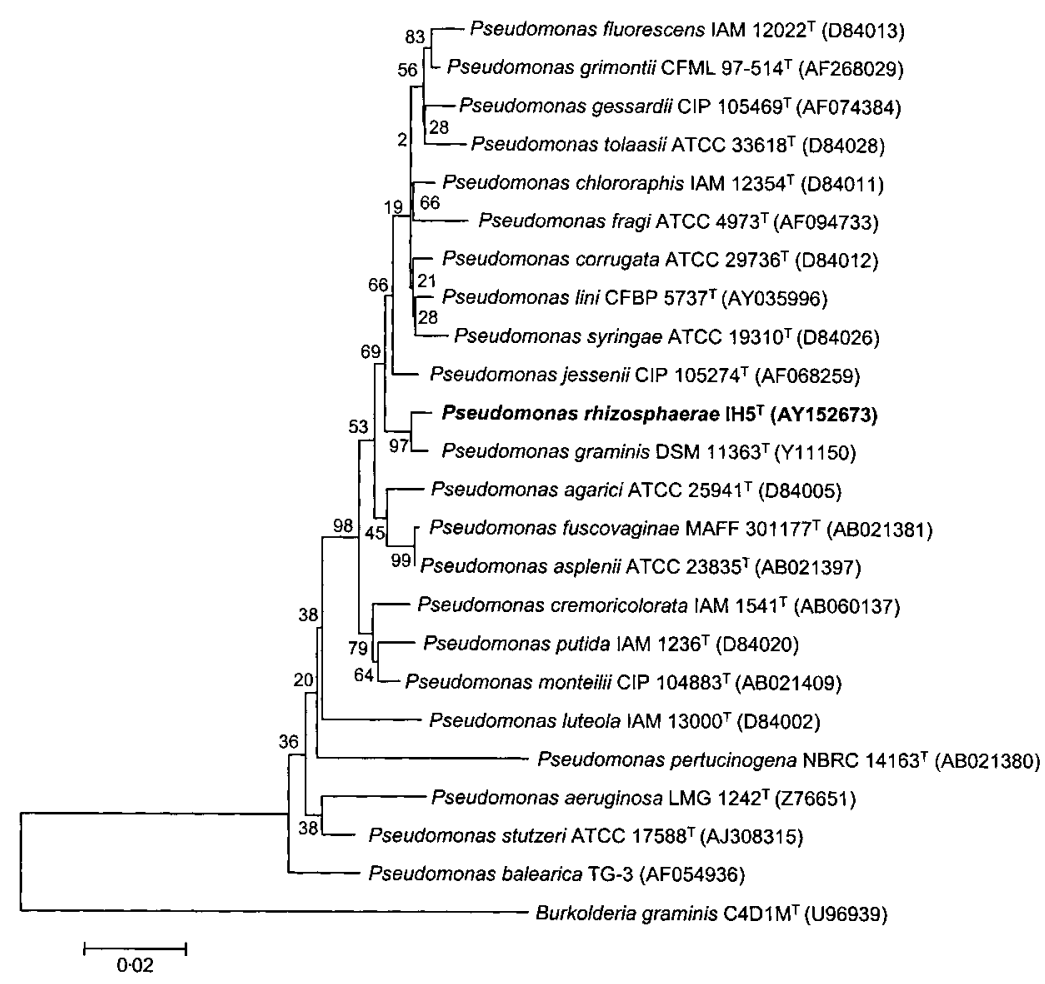

Fig. 1. Comparative sequence analysis of 16S rDNA from Pseudomonas rhizosphaerae $\mathrm{IH}^{\top}$ and species from the genus Pseudomonas sensu stricto with validly published names. Significance of each branch is indicated by a bootstrap value, calculated for 1000 subsets. Bar, 2 substitutions per 100 nt. 
of phenotypic analysis, which showed that $P$. graminis and strain $\mathrm{IH} 5^{\mathrm{T}}$ belong to a separate group of Pseudomonas species that do not produce oxidase or fluorescent pigments. Taking these results into account, DNA-DNA hybridization was performed between $P$. graminis DSM $11363^{\mathrm{T}}$ and strain $\mathrm{IH} 5^{\mathrm{T}}$.

Glucose oxidation and fermentation were tested in the medium described by Hugh \& Leifson (1953). Catalase production was assayed by using $0 \cdot 3 \%(\mathrm{v} / \mathrm{v})$ hydrogen peroxide with a colony taken from YED agar plates. Oxidase activity was detected by using $N, N, N^{\prime}, N^{\prime}$-tetramethyl 1,4 phenylenediamine dihydrochloride $\left(10 \mathrm{~g} \mathrm{l}^{-1}\right)$. P. fluorescens DSM $50090^{\mathrm{T}}$ and P. graminis DSM $11363^{\mathrm{T}}$ were used as positive and negative controls, respectively. Casein activity was detected on skimmed-milk agar after 7 days incubation. Amylases were detected in plates that contained $0.7 \%(\mathrm{w} / \mathrm{v})$ starch as the only carbon source; after 7 days incubation at $28^{\circ} \mathrm{C}$, the plates were stained by using Lugol's solution. For caseinase and amylases, Bacillus cereus DSM $31^{\mathrm{T}}$ and P. graminis DSM $11363^{\mathrm{T}}$ were used as positive and negative controls, respectively. Other physiological and biochemical tests were done by using the API 20NE and API $50 \mathrm{CH}$ strips (bioMérieux), following the manufacturer's instructions. $P$. graminis DSM $11363^{\mathrm{T}}$ was included in these studies and analysed under the same conditions. Ability to solubilize phosphate was tested in YED-P medium as described previously (Peix et al., 2001). Mesorhizobium mediterraneum UPM-Ca36 ${ }^{\mathrm{T}}$ and Sinorhizobium meliloti
ATCC $9930^{\mathrm{T}}$ were used as positive and negative controls, respectively. Pigment analysis was performed according to the method described by Behrendt et al. (1999), using P. graminis DSM $11363^{\mathrm{T}}$ as the reference.

Strain $\mathrm{IH}^{\mathrm{T}}$ showed a great ability to solubilize phosphates on YED-P plates. On the same medium and under the same culture conditions, P. graminis DSM $11363^{\mathrm{T}}$ showed a lower ability to solubilize phosphates: after $24 \mathrm{~h}$ incubation, phosphate solubilization was clearly positive in strain $\mathrm{IH}^{\mathrm{T}}$, but weak in P. graminis DSM $11363^{\mathrm{T}}$. Optimal growth temperature was $25^{\circ} \mathrm{C}$ on nutrient agar. The API 20NE and API $50 \mathrm{CH}$ systems were only used to characterize strain $\mathrm{IH}^{\mathrm{T}}$, because the identification of non-clinical isolates is often wrong. This fact was pointed out by Behrendt et al. (1999) and coincides with the results obtained in our laboratory for many Gram-negative, aerobic, non-enteric isolates (data not shown). Table 1 shows differential phenotypic characteristics between strain $\mathrm{IH} 5^{\mathrm{T}}$ and its closest phylogenetic relatives in the genus Pseudomonas sensu stricto: P. graminis (98.9\% 16S rRNA gene sequence similarity), Pseudomonas jessenii and Pseudomonas agarici ( $>98 \% 16 \mathrm{~S}$ rRNA gene sequence similarity for both). According to the data, strain $\mathrm{IH}^{\mathrm{T}}{ }^{\mathrm{T}}$ is very similar to $P$. graminis, forming a different phenotypic group within the genus Pseudomonas that is characterized by lack of oxidase and fluorescent pigment production. On the other hand, strain $\mathrm{IH} 5^{\mathrm{T}}$ differs from $P$. graminis in aesculin hydrolysis and assimilation of erythritol and rhamnose.

Table 1. Differential characteristics between Pseudomonas rhizosphaerae sp. nov. and closely related species

Species: 1, P. rhizosphaerae $\mathrm{IH} 5^{\mathrm{T}}$ (=LMG $\left.21640^{\mathrm{T}}\right)$; 2, P. graminis; 3, P. agarici; 4, P. jessenii. Data from Holt et al. (1994), Behrendt et al. (1999) and Verhille et al. (1999). +, Positive; -, negative; W, weak; ND, no data available.

\begin{tabular}{|c|c|c|c|c|}
\hline Characteristic & 1 & 2 & 3 & 4 \\
\hline Size $(\mu \mathrm{m})$ & $0 \cdot 8-0 \cdot 9 \times 1 \cdot 2-2 \cdot 4$ & $0 \cdot 5-1 \cdot 0 \times 3 \cdot 5-5 \cdot 0$ & ND & $1 \cdot 2 \times 3 \cdot 3$ \\
\hline Number of polar flagella & 1 & 1 & 1 or 2 & 1 \\
\hline Fluorescent pigments & - & - & + & + \\
\hline Oxidase & - & - & + & + \\
\hline \multicolumn{5}{|l|}{ Growth at: } \\
\hline $4^{\circ} \mathrm{C}$ & + & + & ND & + \\
\hline $41{ }^{\circ} \mathrm{C}$ & - & - & ND & - \\
\hline Acid from glucose & - & - & + & + \\
\hline Phosphate solubilization* $(24 \mathrm{~h})$ & + & $\mathrm{W}$ & ND & ND \\
\hline \multicolumn{5}{|l|}{ Utilization of: } \\
\hline Erythritol & + & - & ND & - \\
\hline Rhamnose & + & - & - & ND \\
\hline \multicolumn{5}{|l|}{ Hydrolysis of: } \\
\hline Aesculin & - & + & - & $\mathrm{ND}$ \\
\hline Casein & - & $+\dagger$ & $\mathrm{ND}$ & ND \\
\hline Gelatin & - & $+\dagger$ & $\mathrm{ND}$ & - \\
\hline
\end{tabular}

${ }^{\star}$ Data from this study (only the type strain of P. graminis, DSM $11363^{\mathrm{T}}$, was tested).

$\dagger$ Some strains give a negative result. 
Table 2. Percentage cellular fatty acid composition of Pseudomonas rhizosphaerae and P. graminis

Species: 1, P. rhizosphaerae $\mathrm{IH}^{\mathrm{T}}\left(=\mathrm{LMG} 21640^{\mathrm{T}}\right)$; 2, P. graminis DSM $11363^{\mathrm{T}}$. Data for $P$. graminis are from Behrendt et al. (1999). The results were obtained by using comparable methods. ND, Not detected.

\begin{tabular}{|lcc|}
\hline Fatty acid & $\mathbf{1}$ & $\mathbf{2}$ \\
\hline $\mathrm{C}_{10: 0} 3-\mathrm{OH}$ & $2 \cdot 9$ & $\mathrm{ND}$ \\
$\mathrm{C}_{12: 0} 2-\mathrm{OH}$ & $2 \cdot 7$ & $0 \cdot 1-2 \cdot 3$ \\
$\mathrm{C}_{12: 0} 3-\mathrm{OH}$ & $4 \cdot 1$ & $0 \cdot 5-2 \cdot 6$ \\
$\mathrm{C}_{12: 0}$ & $4 \cdot 3$ & $0-3 \cdot 4$ \\
$\mathrm{C}_{14: 0}$ & $0 \cdot 3$ & $0 \cdot 2-0 \cdot 3$ \\
$\mathrm{C}_{16: 1}$ & $38 \cdot 6$ & $50 \cdot 1-61 \cdot 4$ \\
$\mathrm{C}_{16: 0}$ & $23 \cdot 3$ & $27 \cdot 4-35 \cdot 5$ \\
$\mathrm{C}_{17: 0}$ & $0 \cdot 2$ & $\mathrm{ND}$ \\
$\mathrm{C}_{18: 1}$ & $23 \cdot 2$ & $2 \cdot 4-17 \cdot 6$ \\
$\mathrm{C}_{18: 0}$ & $0 \cdot 5$ & $\mathrm{ND}$ \\
\hline
\end{tabular}

Analyses of non-polar and hydroxy fatty acids were performed on a culture of strain $\mathrm{IH} 5^{\mathrm{T}}$ grown for $24 \mathrm{~h}$ in TSA medium (Merck) at $28^{\circ} \mathrm{C}$ (Behrendt et al., 1999; Rivas et al., 2003b). The results of the chemotaxonomic analyses are shown in Table 2. The main non-polar fatty acids detected were hexadecenoic acid $\left(\mathrm{C}_{16: 1}\right)$, hexadecanoic acid $\left(\mathrm{C}_{16: 0}\right)$ and octadecenoic acid $\left(\mathrm{C}_{18: 1}\right)$. The hydroxy fatty acids detected were 3-hydroxydecanoic acid $\left(\mathrm{C}_{10: 0}\right.$ 3-OH), 3-hydroxydodecanoic acid $\left(\mathrm{C}_{12: 0} 3-\mathrm{OH}\right)$ and 2-hydroxydodecanoic acid $\left(\mathrm{C}_{12: 0} 2-\mathrm{OH}\right)$. This fatty acid profile is characteristic of strains from rRNA group I (Oyaizu \& Komagata, 1983). According to published data, the cellular fatty acid pattern of $P$. graminis (Table 2 ) is similar to that of strain $\mathrm{IH}^{\mathrm{T}}{ }^{\mathrm{T}}$ (Behrendt et al., 1999). The main difference is the presence of 3-hydroxydecanoic acid $\left(\mathrm{C}_{10: 0} 3-\mathrm{OH}\right)$ in the novel species; this fatty acid was not detected in P. graminis DSM $11363^{\mathrm{T}}$ (Behrendt et al., 1999).

For base composition analysis, DNA was prepared according to Chun \& Goodfellow (1995). DNA G + C content was determined by using the thermal denaturation method (Mandel \& Marmur, 1968). The G + C content was $61 \mathrm{~mol} \%$; this value is similar to those obtained for P. graminis (Behrendt et al., 1999).

For DNA-DNA hybridization analyses, DNA was isolated by chromatography on hydroxyapatite by following the procedure of Cashion et al. (1977), which was carried out as described by De Ley et al. (1970) with the modification described by Huss et al. (1983) and Escara \& Hutton (1980), using a model 2600 spectophotometer equipped with a model 2527-R thermoprogrammer and plotter (Gilford Instrument Laboratories). Renaturation rates were computed with the TRANSFER.BAS program by Jahnke (1992). DNA-DNA homology was tested in $2 \times$ SSC $+10 \%(\mathrm{v} / \mathrm{v})$ DMSO at $68^{\circ} \mathrm{C}$; the results showed $23 \%$ hybridization between strain $\mathrm{IH}^{\mathrm{T}}$ and $P$. graminis DSM $11363^{\mathrm{T}}$. When the recommended threshold value of $70 \%$ DNA-DNA similarity for species definition is considered (Wayne et al., 1987), these results indicate that strain $\mathrm{IH} 5^{\mathrm{T}}$ does not belong to $P$. graminis.

Therefore, on the basis of phylogenetic, chemotaxonomic and phenotypic data, strain $\mathrm{IH}^{\mathrm{T}}$ should be classified as a novel species, for which we propose the name Pseudomonas rhizosphaerae sp. nov.

\section{Differentiation from P. graminis}

From the phenotypic, chemotaxonomic and phylogenetic results of this study, we can conclude that $P$. rhizosphaerae $\mathrm{IH} 5^{\mathrm{T}}$ forms a separate group within the genus Pseudomonas, together with P. graminis. Nevertheless, the novel species can be differentiated from $P$. graminis by phenotypic characteristics, such as aesculin hydrolysis and growth in the presence of rhamnose or erythritol as the sole carbon source. Fatty acid analysis revealed the presence of 3hydroxydecanoic acid $\left(\mathrm{C}_{10: 0} 3-\mathrm{OH}\right)$ in strain $\mathrm{IH}^{\mathrm{T}}$, which was absent in P. graminis [according to the data of Behrendt et al. (1999)]. 16S rRNA gene sequence similarity between $P$. rhizosphaerae and $P$. graminis was $98 \cdot 8 \%$ and DNADNA relatedness was $23 \%$.

\section{Description of Pseudomonas rhizosphaerae sp. nov.}

Pseudomonas rhizosphaerae (rhi.zo.sphae'rae. Gr. fem. n. rhiza root; L. fem. n. sphaera from Gr. fem. n. sphaira ball, globe, sphere; N.L. gen. fem. n. rhizosphaerae of the rhizosphere).

Gram-negative, strictly aerobic, non-spore-forming, rodshaped cells, $1 \cdot 2-2 \cdot 4 \mu \mathrm{m}$ in length and $0 \cdot 8-0 \cdot 9 \mu \mathrm{m}$ in diameter. Motile with one polar flagellum. Colonies on YED agar are circular, convex, yellow, weakly translucent and usually $1-2 \mathrm{~mm}$ in diameter after 2 days growth at $28^{\circ} \mathrm{C}$. Strain $\mathrm{IH} 5^{\mathrm{T}}$ is able to oxidize glucose in medium that contains ammonium nitrate as the nitrogen source and neutral red as a $\mathrm{pH}$ indicator, but is unable to ferment glucose in the same medium. Catalase is produced, but oxidase, gelatinase, caseinase, urease, arginine dehydrolase, tryptophan deaminase, $\beta$-galactosidase, indole and $\mathrm{H}_{2} \mathrm{~S}$ are not. Aesculin is not hydrolysed. Strain $\mathrm{IH}^{\mathrm{T}}{ }^{\mathrm{T}}$ utilizes L-arabinose, D-arabinose, D-xylose, ribose, mannose, galactose, D-fructose, L-sorbose, D-fucose, L-fucose, rhamnose, dulcitol, inositol, sorbitol, mannitol, adonitol, glycerol, erythritol, D-arabitol, gentiobiose, D-turanose, D-tagatose, caprate, malate, gluconate, 2-ketogluconate, 5-ketogluconate and citrate as sole carbon sources. By contrast, it does not grow in $\mathrm{N}$-acetylglucosamine, maltose, adipate or phenylacetate. DNA G + C content of the type strain is $61 \mathrm{~mol} \%$.

The type strain is $\mathrm{IH}^{\mathrm{T}}\left(=\mathrm{LMG} 21640^{\mathrm{T}}=\mathrm{CECT} 5726^{\mathrm{T}}\right)$.

\section{Acknowledgements}

This work was supported by CAICYT-DGES and JCyL (Spanish Government) to E.V. and E.M.-M. and by CLUE and TLINKS 
European Research Projects to C. R.-B. We are grateful to Dr J. Gónzalez and M. Ortíz-Aranda for their help with electron microscopy preparations and to M. Sánchez for his help with $16 \mathrm{~S}$ rDNA sequencing. We are also grateful to Dr Kroppenstedt and Dr Schumann (DSMZ) for their help with the fatty acid methyl ester and DNA-DNA homology analysis, respectively. The authors thank I. Geldart for revising the English version of the manuscript.

\section{References}

Anzai, Y., Kim, H., Park, J.-Y., Wakabayashi, H. \& Oyaizu, H. (2000). Phylogenetic affiliation of the pseudomonads based on 16S rRNA sequence. Int J Syst Evol Microbiol 50, 1563-1589.

Baïda, N., Yazourh, A., Singer, E. \& Izard, D. (2002). Pseudomonas grimontii sp. nov. Int J Syst Evol Microbiol 52, 1497-1503.

Behrendt, U., Ulrich, A., Schumann, P., Erler, W., Burghardt, J. \& Seyfarth, W. (1999). A taxonomic study of bacteria isolated from grasses: a proposed new species Pseudomonas graminis sp. nov. Int J Syst Bacteriol 49, 297-308.

Cashion, P., Holder-Franklin, M. A., McCully, J. \& Franklin, M. (1977). A rapid method for the base ratio determination of bacterial DNA. Anal Biochem 81, 461-466.

Chun, J. \& Goodfellow, M. (1995). A phylogenetic analysis of the genus Nocardia with $16 \mathrm{~S}$ rRNA sequences. Int J Syst Bacteriol 45, 240-245.

De Ley, J., Cattoir, H. \& Reynaerts, A. (1970). The quantitative measurement of DNA hybridization from renaturation rates. Eur J Biochem 12, 133-142.

Delorme, S., Lemanceau, P., Christen, R., Corberand, T., Meyer, J.-M. \& Gardan, L. (2002). Pseudomonas lini sp. nov., a novel species from bulk and rhizospheric soils. Int J Syst Evol Microbiol 52, 513-523.

Deubel, A., Gransee, A. \& Merbach, W. (2000). Transformation of organic rhizodepositions by rhizosphere bacteria and its influence on the availability of tertiary calcium phosphate. J Plant Nutr Soil Sci 163, 387-392.

Di Simine, C. D., Sayer, J. A. \& Gadd, G. M. (1998). Solubilization of zinc phosphate by a strain of Pseudomonas fluorescens isolated from a forest soil. Biol Fertil Soils 28, 87-94.

Doetsch, R. N. (1981). Determinative methods of light microscopy. In Manual of Methods for General Bacteriology, pp. 21-33. Edited by P. Gerdhardt, R. G. E. Murray, R. N. Costilow, E. W. Nester, W. A. Wood, N. R. Krieg \& G. B. Phillips. Washington, DC: American Society for Microbiology.

Escara, J. F. \& Hutton, J. R. (1980). Thermal stability and renaturation of DNA in dimethyl sulfoxide solutions: acceleration of the renaturation rate. Biopolymers 19, 1315-1327.

Felsenstein, J. (1983). Parsimony in systematics: biological and statistical issues. Annu Rev Ecol Syst 14, 313-333.

Gardan, L., Shafik, H., Belouin, S., Broch, R., Grimont, F. \& Grimont, P. A. D. (1999). DNA relatedness among the pathovars of Pseudomonas syringae and description of Pseudomonas tremae sp. nov. and Pseudomonas cannabina sp. nov. (ex Sutic and Dowson 1959). Int J Syst Evol Microbiol 49, 469-478.

Holt, J. G., Krieg, N. R., Sneath, P. H. A., Staley, J. T. \& Williams, S. T. (editors) (1994). Bergey's Manual of Determinative Bacteriology, 9th edn. Baltimore: Williams \& Wilkins.

Hugh, R. \& Leifson, E. (1953). The taxonomic significance of fermentative versus oxidative metabolism of carbohydrates by various gram-negative bacteria. J Bacteriol 66, 24-26.
Huss, V. A. R., Festl, H. \& Schleifer, K.-H. (1983). Studies on the spectrophotometric determination of DNA hybridization from renaturation rates. Syst Appl Microbiol 4, 184-192.

Jahnke, K.-D. (1992). Basic computer program for evaluation of spectroscopic DNA renaturation data from GILFORD system 2600 spectrometer on a PC/XT/AT type personal computer. J Microbiol Methods 15, 61-73.

Jukes, T. H. \& Cantor, C. R. (1969). Evolution of protein molecules. In Mammalian Protein Metabolism, pp. 21-132. Edited by H. N. Munro. New York: Academic Press.

Kimura, M. (1980). A simple method for estimating evolutionary rates of base substitutions through comparative studies of nucleotide sequences. J Mol Evol 16, 111-120.

Kumar, V. \& Singh, K. P. (2001). Enriching vermicompost by nitrogen fixing and phosphate solubilizing bacteria. Bioresour Technol 76, 173-175.

Kumar, S., Tamura, K., Jakobsen, I. B. \& Nei, M. (2001). MEGA2: molecular evolutionary genetic analysis software. Bioinformatics 17, 1244-1245.

Mandel, M. \& Marmur, J. (1968). Use of ultraviolet absorbance temperature profile for determining the guanine plus cytosine content of DNA. Methods Enzymol 12B, 195-206.

Manna, M. C., Ghosh, P. K., Ghosh, B. N. \& Singh, K. N. (2001). Comparative effectiveness of phosphate-enriched compost and single superphosphate on yield, uptake of nutrients and soil quality under soybean-wheat rotation. J Agri Sci 137, 45-54.

Musarrat, J., Bano, N. \& Rao, R. A. K. (2000). Isolation and characterization of 2,4-dichlorophenoxyacetic acid-catabolizing bacteria and their biodegradation efficiency in soil. World J Microbiol Biotechnol 16, 495-497.

Oyaizu, H. \& Komagata, K. (1983). Grouping of Pseudomonas species on the basis of cellular fatty acid composition and the quinone system with special reference to the existence of 3-hydroxy fatty acids. J Gen Appl Microbiol 29, 17-40.

Palleroni, N. J. (1992). Present situation of the taxonomy of aerobic pseudomonads. In Pseudomonas: Molecular Biology and Biotechnology, pp. 105-115. Edited by E. Galli, S. Silver \& B. Witholt. Washington, DC: American Society for Microbiology.

Palleroni, N. J., Kunisawa, R., Contopoulou, R. \& Doudoroff, M. (1973). Nucleic acid homologies in the genus Pseudomonas. Int J Syst Bacteriol 23, 333-339.

Pandey, A. \& Palni, L. M. S. (1998). Isolation of Pseudomonas corrugata from Sikkim Himalaya. World J Microbiol Biotechnol 14, 411-413.

Pearson, W. \& Lipman, D. (1988). Improved tools for biological sequence comparison. Proc Natl Acad Sci U S A 85, 2444-2448.

Peix, A., Rivas-Boyero, A. A., Mateos, P. F., Rodríguez-Barrueco, C., Martínez-Molina, E. \& Velázquez, E. (2001). Growth promotion of chickpea and barley by a phosphate solubilizing strain of Mesorhizobium mediterraneum under growth chamber conditions. Soil Biol Biochem 33, 103-110.

Rivas, R., Velázquez, E., Valverde, A., Mateos, P. F. \& MartínezMolina, E. (2001). A two primers random amplified polymorphic DNA procedure to obtain polymerase chain reaction fingerprints of bacterial species. Electrophoresis 22, 1086-1089.

Rivas, R., Sánchez, M., Trujillo, M. E., Zurdo-Piñeiro, J. L., Mateos, P. F., Martínez-Molina, E. \& Velázquez, E. (2003a). Xylanimonas cellulosilytica gen. nov., sp. nov., a xylanolytic bacterium isolated from a decayed tree (Ulmus nigra). Int J Syst Evol Microbiol 53, 99-103.

Rivas, R., Willems, A., Subba-Rao, N. S., Mateos, P. F., Dazzo, F. B., Kroppenstedt, R. M., Martínez-Molina, E., Gillis, M. \& Velázquez, E. 
(2003b). Description of Devosia neptuniae sp. nov. that nodulates and fixes nitrogen in symbiosis with Neptunia natans, an aquatic legume from India. Syst Appl Microbiol 26, 47-53.

Rodríguez, H. \& Fraga, R. (1999). Phosphate solubilizing bacteria and their role in plant growth promotion. Biotechnol Adv 17, 319-339.

Saitou, N. \& Nei, M. (1987). The neighbor-joining method: a new method for reconstructing phylogenetic trees. Mol Biol Evol 4, 406-425.

Sikorski, J., Stackebrandt, E. \& Wackernagel, W. (2001). Pseudomonas kilonensis sp. nov., a bacterium isolated from agricultural soil. Int J Syst Evol Microbiol 51, 1549-1555.

Singh, S. \& Kapoor, K. K. (1994). Solubilization of insoluble phosphates by bacteria isolated from different sources. Environ Ecol 12, 51-55.

Tajima, F. \& Nei, M. (1984). Estimation of evolutionary distance between nucleotide sequences. Mol Biol Evol 1, 269-285.

Tamura, K. \& Nei, M. (1993). Estimation of the number of nucleotide substitutions in the control region of mitochondrial DNA in humans and chimpanzees. Mol Biol Evol 10, 512-526.

Thompson, J. D., Gibson, T. J., Plewniak, F., Jeanmougin, F. \& Higgins, D. G. (1997). The CLUSTAL_X windows interface: flexible strategies for multiple sequence alignment aided by quality analysis tools. Nucleic Acids Res 25, 4876-4882.

Uchino, M., Shida, O., Uchimura, T. \& Komagata, K. (2001). Pseudomonas parafulva sp. nov. and Pseudomonas cremoricolorata sp. nov. In Validation of the Publication of New Names and New Combinations Previously Effectively Published Outside the IJSEM, List no. 85. Int J Syst Evol Microbiol 52, 685-690.

Vázquez, P., Holguin, G., Puente, M. E., López-Cortez, A. \& Bashan, Y. (2000). Phosphate-solubilizing microorganisms associated with the rhizosphere of mangroves in a semiarid coastal lagoon. Biol Fertil Soils 30, 460-468.

Verhille, S., Baida, N., Dabboussi, F., Izard, D. \& Leclerc, H. (1999). Taxonomic study of bacteria isolated from natural mineral waters: proposal of Pseudomonas jessenii sp. nov. and Pseudomonas mandelii sp. nov. Syst Appl Microbiol 22, 45-58.

Villegas, J. \& Fortín, J. A. (2002). Phosphorus solubilization and $\mathrm{pH}$ changes as a result of the interactions between soil bacteria and arbuscular mycorrhizal fungi on a medium containing $\mathrm{NO}_{3}^{-}$as nitrogen source. Can J Bot 80, 571-576.

Viveganandan, G. \& Jauhri, K. S. (2000). Growth and survival of phosphate-solubilizing bacteria in calcium alginate. Microbiol Res 155, 205-207.

Wayne, L. G., Brenner, D. J., Colwell, R. R. \& 9 other authors (1987). International Committee on Systematic Bacteriology. Report of the ad hoc committee on reconciliation of approaches to bacterial systematics. Int J Syst Bacteriol 37, 463-464.

Yang, Z. (1997). PAML: a program package for phylogenetic analysis by maximum likelihood. Comput Appl Biosci 13, 555-556. 